\title{
The Relationship Between Renewable Energy Consumption, Economic Growth and Carbon Dioxide Emissions in Ethiopia: Empirical Evidence from ARDL Bound Testing Model
}

\author{
Melaku Adinew \\ School of Business and Economics, Dire Dawa University, 1362 , Dire Dawa. Ethiopia
}

\begin{abstract}
Environmental degradation is caused by the use of energy consumption for economic development. The purpose of this study is to examine the relationship between renewable energy consumption and economic growth and $\mathrm{CO}_{2}$ emission in Ethiopia by using annual time series data from 1990 to 2017. The results of the ARDL study show that renewable energy reduces carbon emissions while economic growth increases $\mathrm{CO} 2$ emissions in Ethiopia in both in long run and short run. In light of this result, it is recommended that the government of Ethiopia should develop and introduce such renewable energy sources to replace the growing energy needs of modern businesses. Renewable energy sources can be recycled to reduce carbon emissions and ensure sustainable economic development in Ethiopia.
\end{abstract}

Keywords: Renewable energy, Economic growth, $\mathrm{CO} 2$ emissions, ARDL, Ethiopia

DOI: $10.7176 / \mathrm{JETP} / 10-3-02$

Publication date:July $31^{\text {st }} 2020$

\section{Introduction}

Ethiopia is the second most populous country in Africa and one of the fastest growing countries in the world. Depending on positive recent development, it is possible to reach the middle income level by 2025 (FDRE, 2011). Ethiopia's economy depends on agriculture, and agriculture is a major part of the country, but the growth that is being led by the industry is in progress(EITI, 2014). In addition to this, rapid population growth will result in deforestation(Enbakom et al., 2017).

Ethiopia is facing the problem of deforestation (FDRE, 2019). Increase in industrial sectors use energy for growth that causes environmental degradation. Ethiopia has a high demand of energy for which traditional energy sources are used (EEA, 2019). Traditional energy resources causes carbon dioxide that leads to decline the quality of the environment (Apergis et al., 2010). Environmental degradation affects the environment itself and health of the human being and animals (Danano et al., 2018). Environmental degradation is caused by concentration of greenhouse gas emissions in the atmosphere, including carbon dioxides, nitrous oxide, and methane in Ethiopia(EPCC, 2015). Fossil fuels for daily life and consumption of wood as an energy source boost the $\mathrm{CO} 2$ emissions (EEA, 2019). Carbon dioxide emissions have a destructive impact on the economy and other sectors such as agriculture and forestry.

Several studies are determined the relationship between economic growth, non-renewable energy and CO2 emissions (Aissa \& Safouane, 2017; Ben et al., 2017; Beyene \& Kotosz, 2019; Bhat, 2018; Deng, 2020; Haizam et al., 2019; Hanif, 2018; Hundie, 2018). This is important to understanding the development pattern of developing countries like Ethiopia. The societies rich in natural resources may be able to effectively reduce fossil sources and carbon dioxide emissions. Hundie, (2018) confirmed that energy strategy implementation is validated to decrease dependence on the use of non-renewable energy sources. Non-renewable energy sources still make a big impact energy mix. This shows the sustainability of both sources of energy, i.e., Renewable and non-renewable that can happen in the long run.

The main objective of this research study is to investigate the association between renewable energy consumption, economic growth and carbon dioxide emission in Ethiopia. Different researchers identified that environmental degradation is caused by using non-renewable energy consumption and economic growth in developed countries(Ben \& Ben, 2015; Bhat, 2018; Deng, 2020; Dogan \& Seker, 2016; Haizam et al., 2019; Hanif, 2018; Hundie, 2018). This research study will help to clear the gap between early researches by controlling the model for renewable energy consumption, economic growth, and $\mathrm{CO} 2$ emissions. This research study used econometric techniques the Auto-Regressive Distributive Lag (ARDL) bound testing for co-integration. ARDL model has different advantages as compared to other co-integration method. ARDL model can be implemented if the variables are stationary at level or first difference of both of them while other co-integration methods require similar order of integration. Different lag can be used for dependent and independent variable (Pesaran, Shin and Smith, 2001). This study provides for policy makers to design methods to balance economic growth and environmental quality. 


\section{Literature review}

The relationship between $\mathrm{CO}_{2}$ emission and economic growth is a well-studied. Several studies determined the causal relationship between $\mathrm{CO}_{2}$ emission and economic growth variables in both developing and developed economies. The existing literature has discussed the effect of several factors that it finds significant in explaining the growth of CO 2 emissions. Many studies have deals with the relationship between $\mathrm{CO} 2$ emissions renewable and non-renewable energies consumption and economic growth. These studies have been performed in different countries using different modeling approaches.

More recent study of Kim, (2020) studied the impact of foreign direct investment, economic growth, Industrial structure, renewable and nuclear energy, and urbanization on carbon dioxide in Korean from 1981 to 2014 by utilizing ARDL model for checking the association among the study variables. The examined results indicated that foreign direct Investment, economic growth and urbanization have positively impact the CO2 emissions, while industrial structure and renewable energy have negative impact the $\mathrm{CO} 2$ emissions.

Ito, (2017) using panel data of 42 developing countries to investigated the relationships between growth $\mathrm{CO}$ 2 emissions, renewable and non-renewable energy consumption and economic. The results stated that renewable energy consumption leads to decline $\mathrm{CO} 2$ emissions, while non-renewable energy consumption leads to the increase of CO2 emissions. Sasiwimon and Plyngam, (2017) investigated the causal relationship between energy consumption, CO2 emissions and income in Thailand using the data between 1986 and 2012. The results indicate causality relationship between $\mathrm{CO} 2$ emissions, energy consumption, and income long-run and the evidence supported a bi-directional causality between $\mathrm{CO} 2$ emissions and income, and between $\mathrm{CO} 2$ emissions and energy consumption $\mathrm{n}$ the short run. However, there was no causality between renewable energy consumption and $\mathrm{CO} 2$ emissions in the manufacturing sector.

Jebli \& Youssef, (2015) analyze dynamic causal link between per capita real gross domestic product, combustible renewable and waste consumption and $\mathrm{CO} 2$ emissions for a panel of five North African countries during the period 1971-2008. The result of their study economic growth leads to increase CO 2 emissions. Apergis et al., (2010) determine the link between per capita carbon dioxide (CO2) emissions, per capita real gross domestic product (GDP), renewable energy consumption, and health expenditures as health indicator for a panel of 42 subSaharan Africa countries used panel data the period 1995-2011. The results of FMOLS and DOLS long-run parameter estimates both renewable energy consumption and health expenditures contribute to lower $\mathrm{CO} 2$ emissions, while economic growth increases $\mathrm{CO} 2$ emissions.

Zhang \& Wang, (2019) investigated the impact of renewable energy consumption and service industry development contribute to CO2 emissions reduction in BRICS countries panel data during 1996-2017 and employs the common correlated effects mean group (CCEMG) method. The examined results indicated that renewable energy consumption having negative influence on $\mathrm{CO} 2$ emissions in BRICS countries. Asongu, Chimere,Iheonu and Oda ( 2019) analyze the conditional relationship between renewable energy and environmental quality in a sample of 40 African countries for the period 2002 to 2017 employed a fixed effects regressions. The results suggest that renewable energy decreases $\mathrm{CO} 2$ emissions.

Sinha \& Shahbaz (2018) studied the influences the role renewable energy on CO2 emission in India from 1971-2015 by utilizing the autoregressive distributed lag (ARDL) approach to co-integration for examination of the association among the study variables. The examined results indicated that renewable energy consumption negatively impacts the CO2 emissions. Zaekhan \& Nachrowi, (2017) analyzes the impact of the use of renewable energy, GDP per capita, and other control variables on CO2 emission. The panel data of G-20 countries for the period of 2001-2010 used Fixed Effect Model (FEM) method. The result of the study concludes that increase of urban population, trade openness, and fossil-based energy consumption per capita increase $\mathrm{CO} 2$ emission per capita. While the increase of the use of renewable energy per capita and fossil energy price decline CO2 emission per capita.

\section{Methodology}

\subsection{Unit root test}

Stationarity in time series data is a common problem. It is essential to check the stationarity of the variables before using ARDL model. Traditional methods in applied economics are based on the regularity of the mean, and the variance does not change over time. . However, the mean and variance of many economic components do not remain constant and such variables are known as non-stationarity. A traditional approach (e.g. ordinary least square, OLS) gives biased and unreliable assumptions in the presence of stationary data. In this study, ADF (Dickey \& Fuller, 1979) used to test unit root test.

\subsection{Autoregressive distributive lag}

For this study time series data was collected from world development indicator World Bank, from 1990 to 2017. The period was based on the data availability. Carbon dioxide emissions is used as a measure for environmental degradation, and it is measured as $\mathrm{CO}_{2}$ emission per capita, GDP is used as proxy for economic 
growth, measured as gross domestic product (constant 2010 USD), REN is the share of renewable energy in total final energy are explanatory variables. This study used the theoretical and empirical findings to develop the following model.

$\ln C O_{2 t}=\beta_{0}+\beta_{2} \ln G D P_{t}+\beta_{2} \ln R E N_{t}+\varepsilon_{t}$

Following previous used the bound testing approach proposed by Pesaran, Shin and Smith, (2001) to estimate the long run estimates between $\mathrm{CO}_{2}$ emission, economic growth, renewable energy consumption. The bound testing approach is preferred for several reasons. The ARDL bound testing method is most important if the variables are integrated at the order of $1(0)$ or 1(1), it is useful when the data is small size. The lag adjustment in the ARDL model gives good estimations in the long run and efficient t-statistic in the occurrence of endogenous problems (Pesaran, Shin and Smith, 2001). Therefore, this study used the ARDL method to determined co-integration among renewable energy consumption, $\mathrm{CO}_{2}$ emission and economic growth. The ARDL Bound testing approach is given by the following equations:

$\Delta \ln C O_{2 t}=\beta_{0}+\beta_{1} \ln C O_{2 t-i}+\beta_{2} \ln G D P_{t-i}+\beta_{3} \ln R E N_{t-i}+\sum_{i=1}^{q 1} \delta_{1} \Delta \ln C O_{2 t-i}+\sum_{i=1}^{q 2} \delta_{2} \Delta \ln G D P_{t-i}+$ $\sum_{i-1}^{q 3} \delta_{3} \Delta \ln R E N_{t-i}+\varepsilon_{t}$

$$
\begin{aligned}
& \Delta \ln G D P_{t}=\beta_{0}+\beta_{1} \ln G D P_{t-i}+\beta_{2} \ln C O_{2 t-i}+\beta_{3} \ln R E N_{t-i}+\sum_{i=1}^{q 1} \delta_{1} \Delta \ln G D P_{t-i}+\sum_{i=1}^{q 2} \delta_{2} \Delta \ln C O_{2 t-i}+ \\
& \sum_{i-1}^{q 3} \delta_{3} \Delta \ln R E N_{t-i}+\varepsilon_{t}
\end{aligned}
$$

$\Delta \ln R E N_{t}=\beta_{0}+\beta_{1} \operatorname{lnREN}_{t-i}+\beta_{2} \ln G D P_{t-i}+\beta_{3} \ln C O_{2 t-i}+\sum_{i=1}^{q 1} \delta_{1} \Delta \ln R E N_{t-i}+\sum_{i=1}^{q 2} \delta_{2} \Delta \ln G D P_{t-i}+$ $\sum_{i-1}^{q 3} \delta_{3} \Delta \ln C O_{2 t-i}+\rho_{3} E C T_{t-i}+\varepsilon_{t}$

From the above equations is the ARDL bound testing approach, first difference operation is indicated by $\Delta$, and $\varepsilon_{t}$ is the residual term. The null hypothesis can be tested is $H_{o}: \delta_{0}=\delta_{1}=\delta_{2}=\delta_{3}=\delta_{4}=0$ and alternative hypothesis $H_{0}: \delta_{0} \neq \delta_{1} \neq \delta_{2} \neq \delta_{3} \neq \delta_{4} \neq 0$. This can be determined the long run relationship between the study variables. The F-value indicates the Co-integration among the variables in the bound testing approach. If the calculated F-value greater than the upper bound, reject the null hypothesis. These indicate no cointegration among the variables. The error correction model for the estimation of the short-run relationships is specified as:

$\Delta \ln C O_{2 t}=\beta_{0}+\sum_{i=1}^{q 1} \beta_{1} \Delta \ln C O_{2 t-i}+\sum_{i=1}^{q 2} \beta_{2} \Delta \ln G D P_{t-i}+\sum_{i-1}^{q 3} \beta_{3} \Delta \ln R E N_{t-i}+\rho_{1} E C T_{t-i}+\varepsilon_{t}$

$\Delta \ln G D P_{t}=\beta_{0}+\sum_{i=1}^{q 1} \beta_{1} \Delta \ln G D P_{t-i}+\sum_{i=1}^{q 2} \beta_{2} \Delta \ln C O_{2 t-i}+\sum_{i-1}^{q 3} \beta_{3} \Delta \ln R E N_{t-i}+\rho_{2} E C T_{t-i}+\varepsilon_{t}$

$\Delta \operatorname{lnREN}_{t}=\beta_{0}+\sum_{i=1}^{q 1} \beta_{1} \ln \Delta R E N_{t-1}+\sum_{i=1}^{q 2} \beta_{2} \Delta \ln G D P_{t-1}+\sum_{i=1}^{q 3} \beta_{3} \Delta \ln C O_{2 t-1}+\rho_{3} E C T_{t-i}+\varepsilon_{t}$

In the above equations $\rho_{1}$ to $\rho_{3}$ determined the speed of adjustment; $E C T_{t-i}$ is the lagged error correction term. Then value of $E C T_{t-i}$ to be negative and significant. Breusch-Godfrey was used for checking the serial correlation, Jarque Bera was used for checking normality, Ramsey RESET is used for checking Specification Test, ARCH LM was used for checking Heteroskedasticity and The CUSUM and CUSMSQ are also used for model stability.

\section{Results and Discussions}

Before running the ARDL model, the variables must be checked the stationary level. To investigate the order of integration of each variables of the non-stationarity by applying the Augmented Dickey-Fuller (ADF) test. The tests of the null hypotheses variables are unit root and the alternative hypothesis that the variables are stationary.

\subsection{Unit Root Test Results}

The ARDL bounds test is based on the assumption that the variables are I (0) or I (1) (Pesaran, Shin and Smith, 2001). The unit root test of the variables in level and first difference forms as shown in Table 1, Order of integration is a mixture of I (1). Therefore, the results indicate that all variables are stationary at first difference. 
Table 1 : Results of Unit Root Tests Level of the variables

\begin{tabular}{|c|c|c|c|c|c|c|}
\hline \multirow[b]{2}{*}{ Variables } & \multicolumn{3}{|c|}{ With intercept and without trend } & \multicolumn{3}{|c|}{ With intercept and trend } \\
\hline & Optimal lag & ADF statistics & Decision & Optimal lag & ADF statistics & Decision \\
\hline $\operatorname{lnCO}_{2}$ & 0 & 1.422 & Non-stationary & 0 & -2.549 & Non-stationary \\
\hline $\operatorname{lnGDP}$ & 0 & 2.618 & Non-stationary & 0 & -2.546 & Non-stationary \\
\hline $\operatorname{lnRNE}$ & 0 & 0.705 & Non-stationary & 0 & -2.33 & Non-stationary \\
\hline \multicolumn{7}{|c|}{ First Difference of the Variables } \\
\hline & \multicolumn{3}{|c|}{ With intercept and without trend } & \multicolumn{3}{|c|}{ With intercept and trend } \\
\hline Variables & Optimal lag & ADF statistics & Decision & Optimal lag & ADF statistics & Decision \\
\hline $\operatorname{lnCO} 2$ & 0 & -4.802 & Stationary & 0 & -5.283 & stationary \\
\hline $\operatorname{lnGDP}$ & 1 & -4.882 & Stationary & 1 & -5.824 & stationary \\
\hline $\operatorname{lnREN}$ & 1 & -4.838 & Stationary & 1 & -4.607 & stationary \\
\hline
\end{tabular}

ADF tests with constant and with constant and trend 5\% and level of significance

\subsection{ARDL Bounds tests}

The ARDL bounds test to determine the existence of the long-run relationships and short run dynamic connections among the variables. There is none of co-integration between variables suggests the nonexistence long-run relationship between among the variables. ADRL bound test show the occurrence of long run co-integration even at 5 percent level of significance. Table 2 indicates the results of Bound test. These indicate that the calculated of F-statistic for $\mathrm{F}_{\mathrm{CO} 2}(\mathrm{CO} 2 \mid \mathrm{GDP}, \mathrm{REN})$ value is 8.17 is more than the upper-bound 5 percent critical value. Therefore, there is a long-run relationship among the variables. On the second equation by changed gross domestic product as dependent variable $\mathrm{F}_{\mathrm{GDP}}(\mathrm{GDP} \mid \mathrm{CO} 2, \mathrm{REN})$. The F-statistics value is 9.641 ; this is more than the upper bound. F- Statistics value indicates that co-integration exists at $5 \%$. In the last equation the renewable energy consumption as a dependent variable $\mathrm{F}_{\mathrm{REN}}(\mathrm{REN} \mid \mathrm{CO} 2, \mathrm{GDP})$, results indicated that F-statistics value is 6.473 , which is greater than upper bound, F- statistics result indicates a long-run relationship between the variables at $5 \%$.

Table 2: Bounds test for the existence of Co-Integration

\begin{tabular}{lcc}
\hline Dependent variables & F-Statistics & Outcomes \\
$\mathrm{F}_{\mathrm{CO} 2}(\mathrm{CO} 2 \mid \mathrm{GDP}, \mathrm{REN})$ & 8.17 & Co-integration \\
$\mathrm{F}_{\mathrm{GDP}}(\mathrm{GDP} \mid \mathrm{CO} 2, \mathrm{REN})$ & 9.641 & Co-integration \\
$\mathrm{F}_{\mathrm{REN}}(\mathrm{REN} \mid \mathrm{CO}$, GDP) & 6.473 & Co-integration \\
Critical Bounds Values & & \\
Significance & $\mathrm{I}(0)$ Bound & $\mathrm{I}(1)$ Bound \\
$10 \%$ & 3.17 & 4.14 \\
$5 \%$ & 3.79 & 4.85 \\
$2.50 \%$ & 4.41 & 5.52 \\
$1 \%$ & 5.15 & 6.36 \\
\hline
\end{tabular}

Note: The F-statistic tests the null hypothesis of no co-integration

\subsection{Long-Run ARDL Estimates}

The long run estimation is reported in Table 3 shows the results of long-run coefficients of ARDL model estimation; $\mathrm{CO}_{2}$ emission is the dependent variable and renewable energy consumption and GDP is used to measure the economic growth in Ethiopia.

The coefficient of renewable energy consumption indicates that $1 \%$ increase in the use for renewable energy consumption increase environmental quality by $4072.4 \%$ in Ethiopia. The findings are supported by (Ben et al., 2017; Bhat, 2018; Dogan \& Seker, 2016; Haizam et al., 2019; Hanif, 2018; Sinha \& Shahbaz, 2018; Zaekhan \& Nachrowi, 2017; Zoundi, 2017). It is observed from the previous studies that the use of renewable energy resource decreases pollution and increase quality of environmental by reduce contributing to $\mathrm{CO} 2$ emission. However, mostly developing countries are used non-renewable energy resource for economic activities in that cause the degradation of the environment in of $\mathrm{CO} 2$ emissions. In practice, this would require governments to take a broader approach to mitigating the power supply and in the future enable it to meet the demand for energy and attract foreign investors who provide green technologies.

In developing countries, industrial and other economic activities produce environmental factors that increase carbon emissions in society based on renewable energy sources. The impact of economic development on the environment, economic growth has a positive and significant effect on environmental degradation .Economic growth indicates positively effect on $\mathrm{CO} 2$ emissions in Ethiopia. The coefficient of economic growth shows that $1 \%$ increase in economic growth increases environmental degradation in the economy of Ethiopia about 
63.03\%. The findings are supported (Arouri, et al., 2012; Jebli \& Youssef, 2015; Kim, 2020; Lorente et al., 2018; Mert \& Curve, 2014). Hundie, (2018) indicated that economic growth has a positive effect on CO2 emission, degradation of the environment is caused by economic growth and industrial development.

Table 3: Long Run ARDL Results

\begin{tabular}{ccccc}
\hline Variables & Coefficients & Std. Error & t-Statistic & Probability \\
\hline $\ln$ GDP & 0.6302969 & 0.1862743 & 3.38 & $0.003^{* *}$ \\
$\operatorname{lnREN}$ & -40.72404 & 7.573905 & -5.38 & $0.000^{* *}$ \\
\hline
\end{tabular}

* Indicate statistical significance at $1 \%$ levels

\subsection{Short-Run ARDL Estimates}

The results of short-run ARDL are same as long-run ARDL model presented in table 4. Renewable energy consumption indicates a negative impact on environmental degradation in Ethiopia. Economic growth also causes environmental degradation. Economic growth has a positive effect on the degradation of the environment in Ethiopia. When the economic growth increases causes to increases the $\mathrm{CO} 2$ emissions in developing countries. The coefficient of ECM when $\mathrm{CO}_{2}$ is the dependent variable is negative and statistically significant $1 \%$ level. This implies that, there is the existence of a long-run causality relationship from $\mathrm{CO}_{2}$ to renewable energy consumption and economic growth. The value of ECM coefficient implies that about 54\% of the disequilibrium in $\mathrm{CO}_{2}$ of the previous year's shock adjusted back to the long run equilibrium in the current year.

Table 4: Short Run ARDL Results

\begin{tabular}{lcccc}
\hline Variables & Coefficients & Std. Error & t-Statistic & Probability \\
\hline $\ln$ GDP & 0.3408931 & 0.1546677 & 2.2 & $0.041^{*}$ \\
$\ln$ REN & -12.39012 & 4.189311 & -2.96 & $0.008^{* *}$ \\
$\ln$ REN $(-1)$ & 17.49596 & 5.207679 & 3.36 & $0.003^{* *}$ \\
ECT $(-1)$ & -0.5408452 & 0.147589 & -3.66 & $0.002^{* *}$ \\
\hline
\end{tabular}

$*$ and $* *$ Indicate statistical significance at $5 \%$ and $1 \%$ levels, respectively

\subsection{Diagnostic Tests}

Table 5 shows the results of diagnostic tests include Heteroskedasticity Test, Breusch-Godfrey Serial Correlation LM Test, Jarque-Bera Test and Ramsey RESET Test. The ARDL of Heteroskedasticity was estimated by ARCH LM Test statistic. The results showed that the null hypothesis of no heteroskedasticity cannot reject at the $5 \%$ significance level. The ARDL of serial correlation was estimated by Breusch-Godfrey Serial Correlation LM Test statistic. The estimated result indicates that the null hypothesis of no serial correlation cannot be rejected at the $5 \%$ significance level. This means, no serial correlation exists. ARDL of functional misspecification was estimated by Ramsey RESET Test statistic. The result shows that the null hypothesis of functional form cannot be rejected at the 5\% significance level. This means, there is the ARDL model in its specification form. ARDL of normal distribution was estimated by Jarque-Bera test statistic. The result shows that the null hypothesis of normal distribution cannot be rejected at the 5\% significance level. This indicated that, the residuals are normally distributed.

Table 5: Diagnostic Tests

\begin{tabular}{lll}
\hline Diagnosis & Test & Stats \\
\hline Normality Test & Jarque Bera & JB Stat: $0.32(0.9940)$ \\
Specification Test & Ramsey RESET & F-Stat: $2.30(0.1190)$ \\
Serial Correlation Test & B-G LM Test & Chi-sq: $1.513(0.2187)$ \\
Hetroskedasticity & ARCH LM & Chi-sq: $0.466(0.4948)$ \\
\hline
\end{tabular}

\subsection{Testing for the stability of the model}

The stability of the model is evaluated using the cumulative sum (CUSUM) and the cumulative sum of squares (CUSUMSQ). To examine the stability of the long-run parameter of the ARDL model by using the Cumulative Sum (CUSUM) and Cumulative Sum of Square (CUSUMSQ) of residual test for structural stability proposed by (Pesaran, Shin and Smith, 2001). If the plots of these tests statistics stay within the critical bound of 5\% level of significance, the null hypothesis of all coefficients of the regression are stable and cannot be rejected. Figures (a) and (b), the plots of CUSUM and CUSUMSQ statistics stay within the critical 5\% bound for the period and the coefficients are stable. Therefore, it the plots of both the CUSUM and the CUSUMQ are within the boundaries confirms the stability of the long run coefficients of the model. 

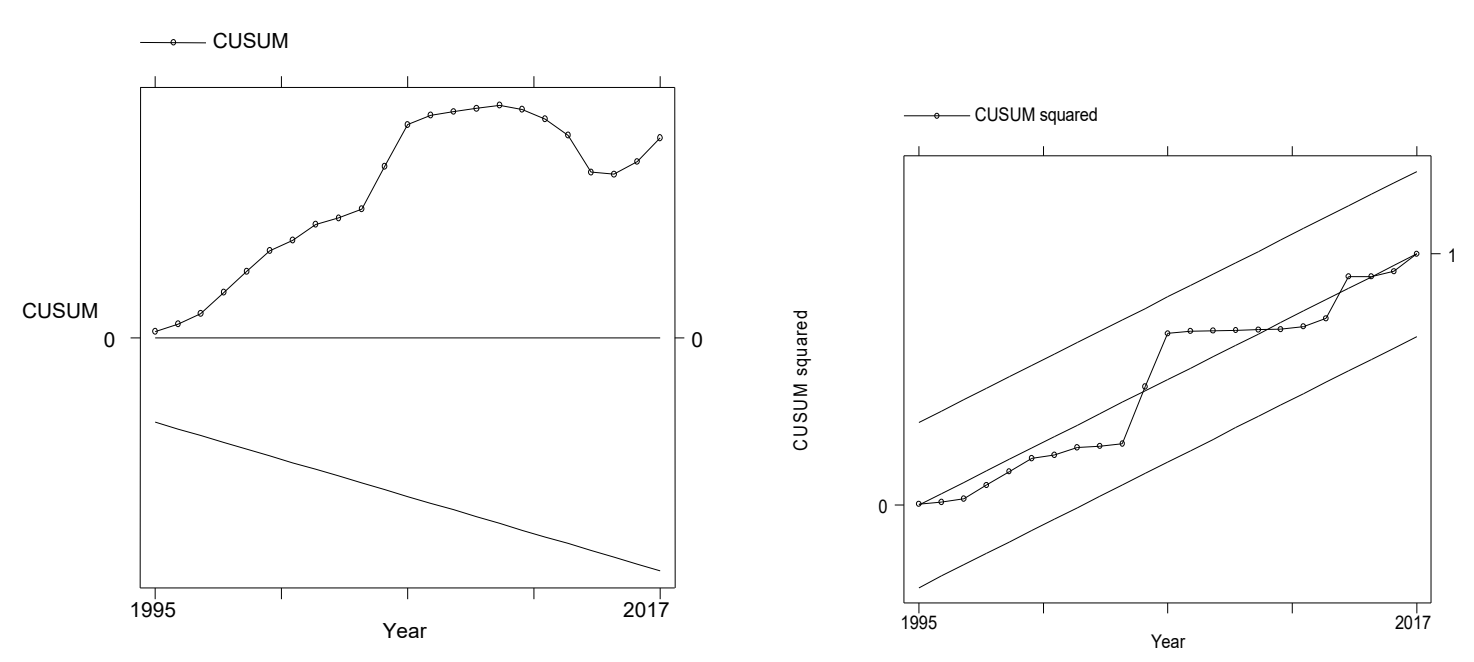

Fig. a: Plots of CUSUM statistics for stability test

Fig. b: Plots of CUSUMQ statistics for stability test

\section{Conclusions and Recommendations}

The objective of this paper is to investigate the relationship between renewable energy consumption, economic growth and $\mathrm{CO}_{2}$ emission in Ethiopia from 1990 to 2017. The Stationarity of variables were checked using Augmented Dickey-Fuller (ADF) unit root tests. The results of the Augmented Dickey-Fuller (ADF) unit Root tests showed that all the time series are stationary at first difference and no variables at second difference. Autoregressive distributed lag (ARDL) was employed for checking co-integration among the variables. Both long-run and short-run ARDL results of renewable energy consumption have a negative effect on $\mathrm{CO} 2$ emissions in Ethiopia. Coefficient of economic growth showed a positive effect on the $\mathrm{CO} 2$ emissions in Ethiopia in both long and short run.

Based on this study, renewable energies consumption is very importance for decreasing of $\mathrm{CO}_{2}$ emissions in Ethiopia. It is recommended that policy makers of Ethiopia should people can be adapted toward plantation to increase forest to manage environmental degradation in Ethiopia. To control the environmental degradations in the long run, a shift in the energy mix towards less polluting energies (renewable energy technologies) would be very important in order to achieve environmental targets as well as the sustainable development of the country. Estimated results also highlight to support renewable sources would decline the per capita emissions. By increasing the utilization of electricity produced from renewable sources will help to mitigate energy dependency and ensure the energy security issue.

\section{Reference}

Aissa, B., \& Safouane, M. (2017). Munich Personal RePEc Archive Renewable and non-renewable energy consumption and economic growth : Evidence from MENA Net Oil Importing Countries Renewable and nonrenewable energy consumption and economic growth: Evidence from MENA Net Oil Abstract : 80780.

Apergis, N., Payne, J. E., Menyah, K., \& Wolde-rufael, Y. (2010). On the causal dynamics between emissions , nuclear energy, renewable energy, and economic growth it. Ecological Economics, 69(11), 2255-2260. https://doi.org/10.1016/j.ecolecon.2010.06.014

Arouri Mohamed El Hedi, YoussefAdel Ben, Hatem M'henni, C. R. (2012). Energy consumption , economic growth and CO 2 emissions in Middle East and North African countries \$. Energy Policy, 45, 342-349. https://doi.org/10.1016/j.enpol.2012.02.042

Ben, M., \& Ben, S. (2015). The environmental Kuznets curve, economic growth, renewable and non-renewable energy, and trade in Tunisia. Renewable and Sustainable Energy Reviews, 47, 173-185. https://doi.org/10.1016/j.rser.2015.02.049

Ben, M., Ben, S., \& Ozturk, I. (2017). Testing environmental Kuznets curve hypothesis : The role of renewable and non-renewable energy consumption and trade in OECD countries. Ecological Indicators, 60(2016), 824831. https://doi.org/10.1016/j.ecolind.2015.08.031

Beyene, S. D., \& Kotosz, B. (2019). Testing the environmental Kuznets curve hypothesis : an empirical study for East African countries. International Journal of Environmental Studies, 00(00), 1-19. https://doi.org/10.1080/00207233.2019.1695445

Bhat, J. A. (2018). Renewable and non-renewable energy consumption - impact on economic growth and CO 2 emissions in five emerging market economies.

Danano, K. A., Legesse, A., \& Likisa, D. (2018). Journal of Remote Sensing \& GIS Monitoring Deforestation in South Western Ethiopia Using Geospatial Technologies. 7(1), 1-5. https://doi.org/10.4172/2469- 


\subsection{9}

Deng, Q. (2020). Greenhouse gas emissions, non-renewable energy consumption, and output in South America : the role of the productive structure. 2014.

Dickey, D. A., \& Fuller, W. A. (1979). Distribution of the Estimators for Autoregressive Time Series With a Unit Root. 74(366), 427-431.

Dogan, E., \& Seker, F. (2016). The in fl uence of real output, renewable and non-renewable energy , trade and fi nancial development on carbon emissions in the top renewable energy countries. Renewable and Sustainable Energy Reviews, 60, 1074-1085. https://doi.org/10.1016/j.rser.2016.02.006

EEA (Ethiopian Energy Authority). (2019). Energy Efficiency Program Administration; the implementation of energy efficiency and conservation in Ethiopia,. Addis Ababa, Ethiopia, January.

Enbakom, H. W., Feyssa, D. H., \& Takele, S. (2017). Impacts of deforestation on the livelihood of smallholder farmers in Arba Minch Zuria Woreda ,. African Journal of Agricultural Research, 12(15), 1293-1305. https://doi.org/10.5897/AJAR2015.10123

EPCC (Ethiopian Panel on Climate Change). (2015). First Assessment Report, Summary of Reports for Policy Makers, Published by the Ethiopian Academy of Sciences.

FDRE(Federal Democratic Republic of Ethiopia). (2019). Ethiopia's Climate Resilient Green Economy. National Adaptation Plan, May.

FDRE (FEDERAL DEMOCRATIC REPUBLIC OF ETHIOPIA). (2011). Ethiopia's Climate-Resilient Green Economy. Addis Ababa, Ethiopia.

Haizam, M., Saudi, M., Sinaga, O., \& Jabarullah, N. H. (2019). The Role of Renewable, Non-renewable Energy Consumption and Technology Innovation in Testing Environmental Kuznets Curve in Malaysia. 9(1), 299307.

Hanif, I. (2018). Impact of economic growth, nonrenewable and renewable energy consumption, and urbanization on carbon emissions in Sub-Saharan Africa.

Hundie, S. K. (2018). Modelling Energy Consumption, Carbon Dioxide Emissions and Economic Growth Nexus in Ethiopia : Evidence from Cointegration and Causality Turkish Journal of Agriculture - Food Science and Technology Modelling Energy Consumption , Carbon Dioxide Emissions . March. https://doi.org/10.24925/turjaf.v6i6.699-709.1720

International Bank for Reconstruction and Development. (2014). Ethiopia Extractive Industries Forum: Ethiopia's Growth and Transformation and Its Extractive Industries Sector. In Addis Ababa, Ethiopia.

Ito, K. (2017). Author' s Accepted Manuscript CO2 emissions, renewable and non - renewable energy consumption, and economic growth: evidence from panel data for developing countries. International Economics. https://doi.org/10.1016/j.inteco.2017.02.001

Jebli, M. Ben, \& Youssef, S. Ben. (2015). Economic growth, combustible renewables and waste consumption, and CO 2 emissions in North Africa. https://doi.org/10.1007/s11356-015-4792-0

Kim, S. (2020). The Effects of Foreign Direct Investment, Economic Growth, Industrial Structure, Renewable and Nuclear Energy, and Urbanization on Korean Greenhouse Gas Emissions. https://doi.org/10.3390/su12041625

Lorente, D., Shahbaz, M., Roubaud, D., \& Farhani, S. (2018). How economic growth , renewable electricity and natural resources contribute to CO 2 emissions? Energy Policy, 113(October 2017), 356-367. https://doi.org/10.1016/j.enpol.2017.10.050

Mert, M., \& Curve, E. K. (2014). THE RENEWABLE ENERGY AND GROWTH : EVIDENCE FOR TURKEY USING ENVIRONMENTAL. 21-34.

Pesaran, M.H., Shin, Y. and Smith, R. . (2001). Bounds testing approaches to the analysis of level relationship. Journal of Applied Economics, 16, 289-326. https://doi.org/10.3390/economies6010002

Sasiwimon W. Paweenawat and Sutida Plyngam. (2017). Does the causal relationship between renewable energy consumption, $\mathrm{CO} 2$ emissions, and economic growth exist in Thailand? An ARDL approach. Economics Bulletin, 37(2), 697-711.

Simplice A. Asongu, C. O. I. and K. O. O. (2019). The Conditional Relationship between Renewable Energy and Environmental Quality in Sub-Saharan Africa. Environmental Science and Pollution Research, November. https://doi.org/10.2139/ssrn.3472463

Sinha, A., \& Shahbaz, M. (2018). Estimation of Environmental Kuznets Curve for CO2 emission: Role of renewable energy generation in India. Renewable Energy. https://doi.org/10.1016/j.renene.2017.12.058

Zaekhan, Z., \& Nachrowi, N. D. (2017). The lmpact of Renewable Energy and GDP per Capita on Carbon Dioxide Emission in the G-20 Countries. March 2015. https://doi.org/10.7454/efi.v60i2.71

Zhang, Y., \& Wang, W. (2019). Do renewable energy consumption and service industry development contribute to CO 2 emissions reduction in BRICS countries? 1955.

Zoundi, Z. (2017a). CO2 emissions, renewable energy and the Environmental Kuznets Curve, a panel cointegration approach. Renewable and Sustainable Energy Reviews, 72(July 2016), 1067-1075. 
https://doi.org/10.1016/j.rser.2016.10.018

Zoundi, Z. (2017b). CO2 emissions, renewable energy and the Environmental Kuznets Curve , a panel cointegration approach $\mathrm{CO} 2$ emissions, renewable energy and the Environmental Kuznets Curve, a panel cointegration approach. Renewable and Sustainable Energy Reviews, 72(October), 1067-1075. https://doi.org/10.1016/j.rser.2016.10.018 